\title{
ДЕНЕЖНО-КРЕДИТНОЕ РЕГУЛИРОВАНИЕ И ЦИФРОВАЯ ЭКОНОМИКА
}

\author{
Мусаев А.Ш., \\ Мусаев Л.А.
}

ГГНТУ им. акад. М.Д. Миллионщикова, г. Грозный, Россия

В статье рассмотрены преимущества и риски, связанные с выпуском цифровых денег, а также определены направления совершенствования Центрального банка РФ по снижению конкурентного давления криптовалют на фиатные деньги

Ключевые слова: денежно-кредитное регулирование, цифровая экономика, криптовалюта, риски

Цифровые технологии проникают во многие сферы экономики. Денежнокредитное регулирование и его главный инструмент - деньги не являются исключением. В последнее время наблюдается тенденция увеличения продаж товаров через интернет, при этом использование наличных денег снижается. Эта новая цифровая экономика предъявляет все новые требования к финансовому сектору, и цифровые деньги появляются как новое платежное средство, которое привлекает потребителей.

Поэтому актуально становится рассмотреть преимущества и риски оцифровки денег, значение цифровых денег для денежно-кредитного регулирования.

Преимуществами использования цифровых денег являются: [2]

- низкие операционные издержки и сетевые эффекты (компании, которые рассматривают возможность запуска цифровых денег, такие как Facebook, имеют огромную базу пользователей) делают его привлекательным для потребителей и предприятия;

- в отличие от банковских переводов, операции с криптовалютами могут быть быстро очищены и рассчитаны без посредников. Преимущества особенно очевидны в трансграничных платежах, которые являются дорогостоящими, громоздкими и непрозрачными;

- предлагают большую часть анонимности наличных денег;

- позволяют осуществлять операции на больших расстояниях;

- единица транзакции потенциально может быть более делимой;

- сокращение времени, необходимого для того, чтобы трансграничные платежи достигли места назначения (с нескольких дней до нескольких секунд, минуя корреспондентские банковские сети);

- в 20-м веке деньги основывались преимущественно на кредитных отношениях: деньги центрального банка или базовые деньги представляют 
собой кредитные отношения между центральным банком и гражданами (в случае наличных денег) и между центральным банком и коммерческими банками (в случае резервов). Деньги коммерческого банка (депозиты до востребования) представляют собой кредитные отношения между банком и его клиентами. Криптовалюты, напротив, не основаны на каких-либо кредитных отношениях, не являются обязательствами каких-либо субъектов и по своей природе больше похожи на товарные деньги.

Однако пользователи цифровых денег, выпущенных частными эмитентами, сталкиваются с четырьмя основными источниками риска: [3]

- ликвидность: например, если каждая единица криптовалюты подкреплена набором активов, номинированных в евро, будет ли у эмитента возможность продать эти активы и конвертировать криптовалюту в евро, для тех пользователей, которые хотят этого, даже в периоды высокого спроса или финансового стресса?

- дефолт: если частный эмитент терпит неудачу, что происходит с криптовалютами, которыми владеют пользователи?

- стоимость: представим, что активы, которые возвращают криптовалюту (например, суверенные облигации, номинированные в евро), внезапно теряют стоимость. Де-факто эмитент выпустит больше цифровых денег, чем должен бы (учитывая новую стоимость активов, которые поддерживают его предложение). В результате она может быть вынуждена «девальвировать» криптовалюту (обменять ее на меньше евро, чем было установлено изначально), что может привести к убыткам для ее пользователей;

- рыночная власть: природа денег приводит к сетевым эффектам (чем больше игроков там используют валюту, тем привлекательнее она как средство платежа), что может привести к естественной монополии: одной валюте «править» все биржи. Таким образом, при отсутствии адекватного регулирования эмитент мог устанавливать барьеры для входа и извлекать доходы от пользователей своей криптовалюты.

Эти индивидуальные риски для пользователя также приводят к другим рискам, влияющим на общество в целом. В частности, с точки зрения экономической политики к ним относятся:

1. Потеря контроля над денежно-кредитной политикой: если криптовалюта, выпущенная частным эмитентом, преобладает над валютой Центрального банка, это подрывает способность центрального банка влиять на предложение денег и процентные ставки, которые действительно влияют на потребителей, вкладчиков и инвесторов в экономике.

2. Риски финансовой устойчивости:

- источник системного риска: если частная криптовалюта будет доминировать в значительной части транзакций, потенциальный сбой или слабость эмитента повлияет на всю систему международных платежей;

- сбои в банковской системе: цифровые деньги предлагают альтернативу банковским депозитам для домашних хозяйств и компаний для хранения своих сбережений. Следовательно, широкое использование цифровых 
денег заставит традиционный банковский сектор конкурировать за депозиты и искать альтернативные источники финансирования (без сомнения, менее стабильные). Это может увеличить стоимость кредита и стимулировать больший риск.

На практике крупные мировые компании начали участвовать в процессе создания новой криптовалюты. Так, например, компания «Facebook» с весны 2018 года начала работу над проектом, которую она назвала «Fasebook Coin», посвященному созданию новой криптовалюты. По мнению руководителей данного проекта, такая криптовалюта не будет подвержена значительным колебаниям, так как у компании наличествуют финансовые средства, которые обеспечат стоимость Fasebook Coin в валюте, которая хранится на банковских счетах компании. Также обеспечением Fasebook Coin, по замыслу авторов проекта, будет несколько валют - доллар и евро, что создадут, по их мнению, дополнительную стабильность. Учитываю, что у компании «Fasebook» огромные возможности по вовлечению миллионов пользователей, например, с помощью мессенджеров WhatsApp - 1,5 млрд. пользователей, Messenger - 1,3 млрд. и Instagram - 1 млрд., разработанная ею новая криптовалюта создаст серьезную конкуренцию нынешним фиатным деньгам [1].

Также сообщается, что такие компании, как «Telegram» и «Signal» работают над созданием собственной криптовалюты. Риск для трех компаний заключается в том, что они могут столкнуться с теми же препятствиями, которые могли бы заблокировать путь другим криптовалютам, таким как биткоин. Отсутствие регулирования и технологических ограничений также может стать тормозом для таких компаний, как Facebook.

С одной стороны, центральные банки развитых стран имеют определенный интерес к тому, чтобы компания «Facebook» запустила тестирование созданной ею криптовалюты, прежде запуска своих. Это даст им возможность определения рисков, связанных с выпуском цифровых денег.

Если деньги центрального банка больше не будут определять расчетную единицу для большинства видов экономической деятельности, и эти расчетные единицы вместо этого будут предоставляться криптоактивами, тогда денежнокредитное регулирование центрального банка становится неактуальной. Аналогией может служить долларизация в экономиках некоторых развивающихся стран. Когда значительная часть внутренней финансовой системы работает с иностранной валютой, денежно-кредитное регулирование в отношении местной валюты становится оторванной от местной экономики.

На наш взгляд, направлениями совершенствования Центрального банка РФ по снижению конкурентного давления криптоактивов на фиатные деньги должны быть следующими:

a) Банк России должен продолжать стремиться к тому, чтобы сделать бумажные валюты лучше и более стабильными единицами учета; при этом Центральный банк РФ должен проводить более эффективное денежнокредитное регулирование, оставаясь открытым для новых идей и новых требований по мере развития экономики. Также надо учитывать, что 
Центральный банк РФ имеет большие данные, искусственный интеллект и машинное обучение, используя которые он сможет улучшить свои экономические прогнозы;

b) правительственные органы должны регулировать использование криптоактивов для предотвращения регулирующего арбитража, и любые несправедливые конкурентные преимущества криптоактивов могут быть получены в результате более легкого регулирования. Это означает неукоснительное применение мер по предотвращению отмывания денег и финансирования терроризма, усиление защиты потребителей и эффективное налогообложение крипто-транзакций;

c) Центральный банк РФ должен продолжать делать свои деньги привлекательными для использования в качестве расчетного инструмента. Например, он мог бы сделать свои деньги удобными для пользователей в цифровом мире, выпуская собственные цифровые знаки в дополнение к физическим денежным средствам и банковским резервам. Такая цифровая валюта Банка России может быть обменена в децентрализованном порядке и равноправна, как криптоактивы.

\section{Исследование выполнено при финансовой поддержке РФФИ в рамках научного проекта №18-010-00182.}

\section{Список литературы}

1. Alexandre Boero. Facebook se prépare à lancer une cryptomonnaie destinée à WhatsApp. Clubic.com (1 mars 2019). Дата обращения 18 апреля 2020. https://www.clubic.com/antivirus-securite-informatique/cryptage-cryptograp hie/crypto-monnaie/actualite-851361-facebook-prepare-lancer-crypto-monnaiedestinee-whatsapp.html.

2. See T. Adrian (2019). «Stablecoins, central bank digital currencies, and cross-border payments: a new look at the international monetary system», speech at the IMF-Swiss National Bank Conference. Furthermore, in countries with fragile institutional systems, it is common for the population to have greater confidence in multinational companies supplying digital money than in their own institutions. https://www.imf.org/en/News/Articles/2019/05/13/sp051419-stablecoins-centralbank-digital-currencies-and-cross-border-payments.

3. The e-monetary policy of the new digital economy. https://www.caixabankresearch.com/en/e-monetary-policy-new-digital-economy. 